УДК 612.015.11-02:616.71/72-018.3-007.248-06:616.37-008.64

DOI 10.11603/1811-2471.2018.v0.i2.8903

\title{
СТАН ПРОТЕОЛІЗУ І АНТИПРОТЕОЛІТИЧНОГО ЗАХИСТУ ПРИ ОСТЕОАРТРОЗІ НА ТЛІ ЕКСКРЕТОРНОЇ НЕДОСТАТНОСТІ ПІДШЛУНКОВОЇ ЗАЛОЗИ
}

\author{
๑л. С. Бабінець, І. М. Галабіцька, Ю. Я. Коцаба \\ ДВНЗ «Тернопільський державний медичний університет імені І. Я. Горбачевського мОз України»
}

\begin{abstract}
РЕзЮМЕ. У статті розглянуті сучасні погляди на патогенез первинного остеоартрозу і проблему коморбідності первинного остеоартрозу та захворювань, що супроводжуються порушенням зовнішньосекреторної функції підшлункової залози. Проаналізовано рівень активації системи протеолізу і системи антипротеолітичного захисту. Дослідниками було встановлено наявність більш глибокого порушення екскреторної функції підшлункової залози (тяжкого ступеня) при остеоартрозі з коморбідними патологіями шлунково-кишкового тракту із зовнішньосекреторною недостатністю підшлункової залози, а також наявність зовнішньосекреторної недостатності підшлункової залози легкого ступеня у I групі хворих на первинний остеоартроз. У хворих на первинний ОА, що перебігав ізольовано або у поєднанні із захворюваннями, що супроводжуються порушенням зовнішньосекреторної функції підшлункової залози, було встановлено статистично значиму активацію загального протеолізу за рівнем протеолітичної активності плазми. Також аналіз засвідчив наявність підвищення специфічного протеолізу, або кініногенезу, за рівнем протеолітичного ферменту калікреїну. Встановлено зниження неактивного попередника калікреїну - прекалікреїну. Був підвищений рівень $a_{1}$-інгібітора протеїназ, який здійснює контроль за активністю протеолізу, зв'язуючи трипсин та протеолітичні ферменти ендо-та екзогенного походження. Виявлено зниження рівня $a_{2}$-макроглобуліну, що свідчить про виснаження інгібіторного захисту організму, адже даний показник блокує кініногеназну дію калікреїну і виводить активні портеїнази ендо- та екзогенного походження. Також було виявлено зниження активності кінінази-ІІ, що свідчить про ослаблення захисних реакцій організму через гіперпродукцію кінінів.
\end{abstract}

КлючовІ СлОВА: первинний остеоартроз; порушення зовнішньосекреторної функції підшлункової залози.

Вступ. Первинний остеоартроз (ОА) - хронічне прогресуюче дегенеративно-дистрофічне захворювання суглобів, що характеризується дегенерацією суглобового хряща з подальшими змінами субхондральної кістки і розвитком крайових остеофітів, часто супроводжується реактивним синовіїтом.

Характерною ознакою деструкції хряща при OA $\epsilon$ втрата матриксом глікозаміногліканів-хондроїтинсульфату, кератинсульфатів, гіалуронової кислоти. Крім того, відзначається зменшення молекул протеогліканів, які набувають здатності до виходу з матриксу хряща.

При пошкодженні хондроцитів вони продукують невластиві нормальній хрящовій тканині колаген і протеоглікани (короткий колаген, що не утворює фібрил, і низькомолекулярні дрібні молекули протеогліканів), нездатні формувати агрегати з гіалуроновою кислотою, що призводить до втрати біохімічних властивостей матриксу хряща.

Значну роль у патогенезі ОА відіграє запалення. Механізмом, за допомогою якого запалення бере участь у деградації хряща, $\epsilon$ продукція прозапальних цитокінів (ІЛ-1 $\beta$, ІЛ-6, ФНП-а тощо), які, своєю чергою, вивільняють ферменти, що пошкоджують колаген (колагеназу, еластазу, пептидази), і протеоглікани (металопротеїнази, стромелі- зин, катепсини), а також активують протеолітичну активність, що призводить до підвищеного руйнування гіалуронових волокон і зниження регенерації хряща [2].

Дослідження також виявили високу частоту при ОА захворювань шлунково-кишкового тракту (ШКТ), особливо тих, що супроводжуються порушенням зовнішньосекреторної функції підшлункової залози (ПЗ), що також сприяє активації протеолізу $[1,3,4]$. Зовнішньосекреторна недостатність ПЗ (ЗСНПЗ) при ОА формується як наслідок коморбідних патологій, для яких вона притаманна (хронічний панкреатит (ХП) із ЗСН ПЗ та формуванням інкреторної недостатності у формі цукрового діабету (ЦД), функціональні біліарні порушення, захворювання печінки та жовчовивідної системи, хвороби гастродуоденальної зони, ентероколіт і дисбіоз кишечника), так і внаслідок довготривалого лікування ОА з використанням нестероїдних протизапальних препаратів, глюкокортикоїдів, хондропротекторів і хондростимуляторів тощо. 3 огляду на вищенаведене вважаємо актуальним дослідити стан системи протеолізу при перебігу ОА на тлі ЗСНПЗ, оскільки ці взаємодіючі фактори та ризики потрібно враховувати при узгодженні комплексної терапії та реабілітації таких хворих. 
Огляди літератури, оригінальні дослідження, погляд на проблему, ювілеї

Мета роботи - вивчити ступінь активації системи протеолізу у хворих на первинний ОА на тлі порушення у них зовнішньосекреторної функції підшлункової залози.

Матеріал і методи дослідження. Було обстежено 32 амбулаторних пацієнти з первинним ОА (I група) і 37 - з первинним ОА у поєднанні із захворюваннями, що супроводжуються ЗСНПЗ (II група). Критеріями виключення були онкологічні захворювання, гострі та загострення хронічних патологій життєво важливих органів, тяжкий ЦД, ЦД 1 типу, активні виразки шлунка та дванадцятипалої кишки, вірусні гепатити та цирози печінки, хвороба Крона, неспецифічний виразковий коліт, муковісцидоз. Вік хворих становив від 29 до 74 років. Контрольну групу складали 30 здорових людей. Діагноз первинного ОА встановлювали на основі уніфікованих діагностичних критеріїв, рентгенологічну стадію первинного ОА - за J. H. Kellgren i J. S. Lawrence [5]. Ступінь ЗСНПЗ визначали за рівнем фекальної еластази-1, яку визначали методом імуноферментного аналізу за допомогою стандартних наборів фірми Bioserv Elastase-1-Elisa. Протеолітичну активність плазми (ПРА) визначали за гідролізом протамінсульфату. Активність калікреїну (КК) досліджували за допомогою методу, що базується на визначенні кількості паранітроаніліну, який відщеплюється під дією КК від синтетичного субстрату хромозиму РК. Прекалікреїн (ПКК) визначали за методом Веремєєнка. Активність $a_{1}$-інгібітора протеїназ ( $a_{1}-$-ІП) та $a_{2}$-макроглобуліну ( $\left.a_{2}-\mathrm{M \Gamma}\right)$ визначали уніфікованим спектрофотометричним методом. Визначення активності кінінази-ІІ проводили спектрофотометричним методом Фолька.

Результати й обговорення. Аналіз отриманих показників рівнів фекальної еластази-1 у гру- пах дослідження показав наявність 3СНП3 в обох групахдослідження-відповідно $(153,83 \pm 5,34)$ мкг/г і $(58,65 \pm 4,73)$ мкг/г -у порівнянні з групою контролю $((213 \pm 6,29)$ мкг/г), а також статистично достовірно нижчий рівень фекальної еластази у II групі, порівняно з таким у I групі $(p<0,05)$. Це констатувало наявність більш глибокого порушення екскреторної функції ПЗ (тяжкого ступеня) при ОА з коморбідними патологіями ШКТ із ЗСНПЗ, а також наявність ЗСНПЗ легкого ступеня у I групі хворих на ОА. Вищенаведене підтверджує думку про необхідність дослідження цієї проблеми для урахування фактора наявності ЗСНПЗ при формуванні ефективного комплексу реабілітації хворих на ОА з коморбідними патологіями ШКТ.

Було виявлено статистично значиму активацію загального протеолізу за рівнем ПРА у обох досліджуваних групах, проте у групі пацієнтів 3 первинним ОА на тлі ЗСНПЗ активація ПРА була статистично більш значущою. Також аналіз засвідчив наявність підвищення специфічного протеолізу, або кініногенезу, за рівнем протеолітичного ферменту КK, який відіграє найбільше значення в утворенні кінінів у групі з коморбідною патологією. Встановлено зниження неактивного попередника КК - ПКК - у обох досліджуваних групах, проте у II групі зниження було статистично значимо вагомішим. Був підвищений рівень $a_{1}-$ ІП статистично значимо найбільше у II групі, порівняно з I групою і групою контролю. Констатовано статистично значиме зниження рівня $\mathrm{a}_{2}-\mathrm{MГ}$ у I i II групах, проте у II групі зменшення рівня даного показника було статистично значущішим. Також було виявлено зниження активності кінінази-II, статистично значиме при коморбідності первинного ОА із захворюваннями ШКТ із ЗСНПЗ $(p<0,05)$.

Таблиця 1. Стан показників протеолізу у хворих на ОА залежно від наявності ЗСНПЗ

\begin{tabular}{|l|c|c|c|}
\hline \multirow{2}{*}{ Показник протеолізу } & \multicolumn{3}{|c|}{ Група порівняння } \\
\cline { 2 - 4 } & контроль $(\mathrm{n}=30)$ & 1 група $(\mathrm{n}=32)$ & 2 група $(\mathrm{n}=37)$ \\
\hline ПРА, ммоль аргініну/ (год.л) & $30,41 \pm 0,71$ & $43,36 \pm 2,54^{*}$ & $48,42 \pm 2,28^{* *}$ \\
\hline КК, мКмоль/(хв.Л) & $54,12 \pm 1,43$ & $139,78 \pm 5,67^{*}$ & $151,65 \pm 7,44^{* *}$ \\
\hline ПКК, мКмоль/(хв.л) & $74,79 \pm 1,89$ & $51,26 \pm 2,47^{*}$ & $45,18 \pm 4,34^{* *}$ \\
\hline $\mathrm{a}_{1}$-ІП, г/л & $1,43 \pm 0,02$ & $1,68 \pm 0,03^{*}$ & $1,74 \pm 0,04^{* *}$ \\
\hline $\mathrm{a}_{2}$-МГ, г/л & $1,45 \pm 0,02$ & $0,95 \pm 0,03^{*}$ & $0,85 \pm 0,06^{* *}$ \\
\hline $\begin{array}{l}\text { АКТивність кінінази-ІІ, } \\
\text { мКмоль ГК/(хв.л) }\end{array}$ & $271,38 \pm 1,45$ & $185,32 \pm 3,31^{*}$ & $172,45 \pm 7,86^{* *}$ \\
\hline
\end{tabular}

Примітка. * - статистично значима різниця показників стосовно групи контролю $(p<0,05)$;

** - статистично значима різниця показників II клінічної групи стосовно I групи $(p<0,05)$.

Висновки. 1. Було доведено наявність більш глибокого порушення екскреторної функції підшлункової залози (тяжкого ступеня) при ОА з коморбідними патологіями ШКТ із ЗСНПЗ, а також наявність ЗСНПЗ легкого ступеня у хворих на ОА без наявної клінічно ЗСНПз.

2. У хворих на первинний ОА, що перебігав ізольовано або у поєднанні із захворюваннями, що 
Огляди літератури, оригінальні дослідження, погляд на проблему, ювілеї

супроводжуються порушенням зовнішньосекреторної функції підшлункової залози, було встановлено статистично значиму активацію загального протеолізу за рівнем ПРА. Також аналіз засвідчив наявність підвищення специфічного протеолізу, або кініногенезу, за рівнем протеолітичного ферменту КК. Встановлено зниження неактивного попередника КК - ПКК. Був підвищений рівень $\mathrm{a}_{1}-\mathrm{IП}$, який здійснює контроль за активністю протеолізу, зв'язуючи трипсин та протеолітичні ферменти ендо- та екзогенного походження. Виявлено зниження рівня $\mathrm{a}_{2}-\mathrm{MГ}$, що свідчить про виснаження інгібіторного захисту організму, адже даний показник блокує кікіногеназну дію КК і виводить активні протеїнази ендо- та екзогенного походження. Також було виявлено зниження активності кінінази-ІІ, що свідчить про ослаблення захисних реакцій організму через гіперпродукцію кінінів $(p<0,05)$.

\title{
ЛІТЕРАТУРА
}

1. Improvement of the complex medical treatment for the patients with chronic biliary pancreatitis / L. S. Babinets, K. Y. Kytsai, Y. Y. Kotsaba [et al.] // Wiadomosci lekarskie. - 2017. - No. 2. - P. 213-216.

2. Hochberg M. Osteoarthritis year 2012 in review: clinical / M. Hochberg // Osteoarthritis Cartilage. - 2012. No. 20. - P. 1465-1469.

3. Бабінець Л. С. Зовнішньосекреторна недостатність підшлункової залози та дисбаланс системи прооксиданти-антиоксиданти при первинному остеоартрозі з коморбідними станами / Л. С. Бабінець, І. М. Галабіцька,

Т. Г. Маєвська // Здобутки клінічної і експериментальної медицини. - 2017. - № 3. - С. 22-25.

4. Бабінець Л. С. Клініко-патогенетичні аспекти остеодефіциту при остеоартрозі у поєднанні з хронічним панкреатитом / Л. С. Бабінець, Т. Г. Маєвська // Здобутки клінічної і експериментальної медицини. - 2017. № 2. - С. 31-37.

5. Уніфікований клінічний протокол первинної, вторинної (спеціалізованої) медичної допомоги та медичної реабілітації / Міністерство охорони здоров'я України 10.09.2014, № 638.

\section{REFERENCES}

1. Babinets, L.S., Kytsai, K.Yu., Kotsaba, Yu.Ya., Halabitska, I.M., \& Melnyk, N.A. (2017). Improvement of the complex medical treatment for the patients with chronic biliary pancreatitis. Wiadomosci Lekarskie, 2, 213-216.

2. Hochberg, M. (2012). Osteoarthritis year 2012 in review: clinical. Osteoarthritis Cartilage, 20, 1465-1469.

3. Babinets, L.S., Halabitska, I.M., Maievska, T.H. (2107). Zovnishnosekretorna nedostatnist pidshlunkovoi zalozy ta dysbalans systemy prooksydanty-antyoksydanty pry pervynnomu osteoartrozi z komorbidnymy stanamy [Externalsecretion pancreatic insufficiency and an anti-oxidant antioxidant system imbalance in primary osteoarthritis with comorbid conditions]. Zdobutky klinichnoi ta eksperymentalnoi medytsyny-Achievements of Clinical and Experimental Medicine, 3, 22-25 [in Ukrainian].

\section{СОСТОЯНИЕ ПРОТЕОЛИЗА И АНТИПРОТЕОЛИТИЧЕСКОЙ ЗАЩИТЫ ПРИ ОСТЕОАРТРОЗЕ НА ФОНЕ ЭКСКРЕТОРНОЙ НЕДОСТАТОЧНОСТИ ПОДЖЕЛУДОЧНОЙ ЖЕЛЕЗЫ}

4. Babinets, L.S., \& Maievska, T.H. (2017). Klinikopatohenetychni aspekty osteodefitsytu pry osteoartrozi u poiednanni z khronichnym pankreatytom [Clinical and pathogenetic aspects of osteodyphritis in osteoarthritis in combination with chronic pancreatitis]. Zdobutky klinichnoi ta eksperymentalnoi medytsyny - Achievements of Clinical and Experimental Medicine, 2, 31-37 [in Ukrainian].

5. Unifikovanyi klinichnyi protokol pervynnoi, vtorynnoi (spetsializovanoi) medychnoi dopomohy ta medychnoi reabilitatsii [Unified clinical protocol of primary, secondary (specialized) medical aid and medical rehabilitation]. (2014). Ministry of Health of Ukraine, 638 [in Ukrainian].

\author{
○Л. С. Бабинец, И. М. Галабицкая, Ю. Я. Коцаба
}

ГВУз «Тернопольский государственный медицинский университет имени И. Я. Горбачевского МЗ Украины»

РЕЗЮМЕ. В статье рассмотрены современные взгляды на патогенез первичного остеоартроза и проблему коморбидности первичного остеоартроза и заболеваний, сопровождающихся нарушением внешнесекреторной функции поджелудочной железы. Проанализирован уровень активации протеолиза и системы антипротеолитической защиты. Исследователями было установлено наличие более глубокого нарушения экскреторной функции поджелудочной железы (тяжелой степени) при остеоартрозе с коморбидными патологиями желудочно-кишеч- 
Огляди літератури, оригінальні дослідження, погляд на проблему, ювілеї

ного тракта с внешнесекреторной недостаточностью поджелудочной железы, а также наличие внешнесекреторной недостаточности поджелудочной железы легкой степени в I группе больных первичным остеоартрозом. У больных первичным ОА, котрий проходил изолированно или в сочетании с заболеваниями, сопровождающимися нарушением внешнесекреторной функции поджелудочной железы, была установлена статистически значимая активация общего протеолиза по уровню протеолитической активности плазмы. Также анализ показал наличие повышения специфического протеолиза, или кининогенеза, по уровню протеолитического фермента калликреина. Установлено снижение неактивного предшественника калликреина - прекалликреина. Был повышен уровень $a_{1}$-ингибитора протеиназ, который осуществляет контроль за активностью протеолиза, связывая трипсин и протеолитические ферменты эндо- и экзогенного происхождения. Выявлено снижение уровня $a_{2}$-макроглобулина, что свидетельствует об истощении ингибиторной защиты организма, поскольку данный показатель блокирует кикиногеназное действие калликреина и выводит активные портеиназы эндо- и экзогенного происхождения. Также было выявлено снижение активности кининазы-ІІ, что свидетельствует об ослаблении защитных реакций организма через гиперпродукцию кининов.

КЛЮчЕВЫЕ СЛОВА: первичный остеоартроз; нарушения внешнесекреторной функции поджелудочной железы.

\section{STATE OF PROTEOLYSIS AND ANTIPROTEOLYTIC PROTECTION IN OSTEOARTHROSIS ON THE BACKGROUND OF EXCRETORY PANCREATIC INSUFFICIENCY}

\section{OL. S. Babinets, I. M. Halabitska, Yu. Ya. Kotsaba}

\section{Horbachevsky Ternopil State Medical University}

SUMMARY. The article considers modern views on the pathogenesis of primary osteoarthritis and the problem of comorbidity of primary osteoarthritis and diseases that are accompanied by a violation of the external secretion function of the pancreas. The level of activation of the proteolysis system and the system of antiprotoolithic protection has been analyzed. Researchers found that there is a deeper excitation of the excretory function of the pancreas (severe) in osteoarthritis with comorbid pathologies of the gastrointestinal tract with external secretion of the pancreas, as well as the presence of external secretion of the pancreas of the lung in the group I of patients with primary osteoarthritis. In patients with primary OA, which run in isolation or in combination with diseases that were accompanied by a violation of the external secretion function of the pancreas, a statistically significant activation of the total proteolysis by the level of the proteolytic activity of the plasma was established. Also, the analysis showed the presence of an increase in specific proteolysis, or kininogenesis, by the level of proteolytic enzymes of kallikrein. The decrease in the inactive precursor of kallikrein - prekalikrein was established. There was an elevated $a_{1}$-proteinase inhibitor level, which monitors the activity of proteolysis by binding trypsin and proteolytic enzymes of endo- and exogenous origin. A decrease in the level of $a_{2}-$ macroglobulin has been detected, indicating the depletion of the inhibitory protection of the organism, since this indicator blocks the kininogenase action of kallicreatin and displays active porteinases of endo- and exogenous origin. Also, decreased activity of kininase-II was revealed, which indicates weakening of the protective reactions of the organism through hyperproduction of kinins.

KEY WORDS: primary osteoarthrosis; diseases accompanied by violation of the pancreas external secretion function.

Отримано 25.02.2018 